\title{
Erratum to: Nutrient requirements in Hanwoo cows with artificial insemination: effects on blood metabolites and embryo recovery rate
}

\author{
Sung-Sik Kang, Ui-Hyung Kim, Man-Hye Han and Sang-Rae Cho* \\ Hanwoo Research Institute, National Institute Animal Science (NIAS), Rural Development \\ Administration (RDA), Pyeongchang 25340, Korea
}

${ }^{*}$ Corresponding author

Sang-Rae Cho

Hanwoo Research Institute, NIAS,

RDA, Pyeongchang 25340, Korea.

Tel: +82-33-330-0625

E-mail: davidcho5020@gmail.com

Copyright ( $\odot 2020$ Korean Society of Animal Sciences and Technology. This is an Open Access article distributed under the terms of the Creative Commons Attribution

Non-Commercial License (http:// creativecommons.org/licenses/bync/4.0/) which permits unrestricted non-commercial use, distribution, and reproduction in any medium, provided the original work is properly cited.

ORCID

Sung-Sik Kang

https://orcid.org/0000-0002-9453-5377

Ui-Hyung Kim

https://orcid.org/0000-0002-2197-5080

Man-Hye Han

https://orcid.org/0000-0002-8104-4587

Sang-Rae Cho

https://orcid.org/0000-0003-0209-6248

\section{ERRATUM}

In the published article "Nutrient requirements in Hanwoo cows with artificial insemination: effects on blood metabolites and embryo recovery rate. J Anim Sci Technol. 2020;62(4):449-459. https://doi. org/10.5187/jast.2020.62.4.449," the funding sources have to be modified. The editorial office will report that this amendment is made at the request of the author.

\section{FUNDING SOURCES}

This work was carried out with the support of the "Cooperative Research Program for Agriculture Science \& Technology Development (project title: Study on Reproductive Efficiency Improvement according to the Survey on the Breeding Condition of Hanwoo Breeding Farm, Project No. PJ014326012019)" Rural Development Administration, Korea. This study was supported by 2019 RDA Fellowship Program of Hanwoo Research Institute, Rural Development Administration, Korea.

\section{REFERENCE}

1. Kang SS, Kim UH, Han MH, Cho SR. Nutrient requirements in Hanwoo cows with artificial insemination: effects on blood metabolites and embryo recovery rate. J Anim Sci Technol. 2020;62:449-59. https://doi.org/10.5187/jast.2020.62.4.449 